ISSN 2414-1143

Научный альманах стран Причерноморья. 2018. Том 15. № 3

DOI 10.23947/2414-1143-2018-15-3-47-54

UDC 39(419)(470.61)

\title{
TRADITITIONAL TURKISH AND COSSACK WEDDING CEREMONIES: GENERAL AND PECULIAR (SAFRANBOLU AND COSSACK VILLAGE NIZHNE-KUNDRYUCHENSKOJ EXAMPLES)
}

\author{
(C) Kseniya A. Milenkaya, Marina I. Zhbannikova \\ State Archive of the Rostov region, \\ Moscow University named after S.Y. Vitte (branch) \\ Rostov-on-Don, Russian Federation
}

A comparative analysis of a traditional wedding ritualism in Turkish and Cossack cultures on the example of Safranbolu region and Cossack village Nizhne-Kundryuchenskoj. A wedding ritualism is regarded as inherent human need in ritualization important vital events, the preservation of the ancestral memory of wedding traditions in songs, tales etc. Turkish and Cossack principles of marriage proposal in these regions are analyzed. Cossack wedding traditions of the 19th century combined pagan beliefs and Christianity. Such a synthesis is typical for the traditional Turkish wedding, where along with the Islamic traditions there are remnants of the prelslamic period. For thousands of years, the traditions of many peoples of Anatolia, the Mediterranean region, the Middle East, the Caucasus, Eastern Europe, Central Asia and, of course, the ancient world have merged into an unexpected amalgamation, which today is commonly called the Turkish, or Asia Minor culture. This paper explores special features of rituals and traditions accompanying marriage ceremonies in Safranbolu and Nizhne-Kundryuchenskoj. Community rituals historically accompanied the most important events in a human life in Ancient Russia and Turkey. They were sacred being carefully passed through the generations. Many strange traditions were perfectly kept up to now. A contemporary challenge nowadays is to optimize cooperation of cultures and rituals between nations with different upbringing and development of the person based on local traditions. ditions.

Key words: Turkey, Safranbolu, Nizhne-Kundryuchenskoj, wedding traditions, Cossacks, culture, tra-

[К.А. Миленькая, М.И. Жбанникова Традиционные турецкие и казачьи свадебные обряды: общее и особенное (на примере Сафранболу и станицы Нижне-Кундрюченской)]

Предлагается сравнительный анализ традиционной свадебной обрядности в казачьей и турецкой культуре на примере региона Сафранболу и станицы Нижне-Кундрюченской. Традиционная свадебная обрядность рассматривается как присущая человеку потребность в ритуализации важных жизненных событий, сохранение живой памяти предков о свадебных традициях в песнях, присказках и пр. Анализируются принципы сватовства у казаков и турок указанных регионов. Свадебные традиции казаков XIX века соединили в себе языческие верования и христианство. Подобный синтез характерен и для традиционной турецкой свадьбы, где наряду с мусульманскими традициями присутствуют и пережитки доисламского периода. За тысячи лет традиции многих народов Анатолии, Средиземноморья, Ближнего Востока, Кавказа, Восточной Европы, Средней Азии и, конечно, античного мира слились в оригинальный сплав, который в наши дни принято обобщенно называть турецкой, или малоазийской культурой. Исследуются особенности обрядов и традиций, сопровождающих брачную церемонию в Сафранболу и Нижне-Кундрюченской. Народные обряды издавна сопровождали на Руси и в Турции самые значимые события в жизни человека. Их свято почитали, бережно передавая из поколения в поколение. Многие старинные обычаи сохранились до наших дней. Актуальной задачей в настоящее время становится оптимизация взаимодействия культур и обрядов между народами разных стран по воспитанию и развитию личности на народных традициях.

Ключевые слова: Турция, Сафрранболу, Нижне-Кундрюченская, свадебные обычаи, казаки, культура, традиции. 
Kseniya A. Milenkaya - head of the Informational and Publication Department of the Rostov Region State Archive, Russian Federation.

Миленькая Ксения Анатольевна - заведующая отделом информации и публикации Государственного архива Ростовской области, Россия.

Marina I. Zhbannikova - Leading archeograph of the Rostov Region State Archive, Lecturer S.U. Vitte Moscow University affiliate in c. Rostov-on-Don, Russian Federation.

Жбанникова Марина Исматовна - ведущий археографь Государственного архива Ростовской области, преподаватель. Московский университет им. С.Ю. Витте, филиал в г. Ростове-на-Дону, Россия.

Creating a family and ensuring unity in society, as well as in Turkish one, have always been important and interrelated issues. Marriage is accompanied by certain ritual actions, the so-called rites of passage, symbolizing the change of one social category to another. The concept of such rallies was first formulated by the famous French folklorist and ethnograph Arnold van Gennepom in 1909 [1]. The most common rites of the passage of one social category to another are accompanied by certain stages, spread in most cultures. These are birth, achievement of social maturity, marriage, paternity, promotion of social status, professional specialization, death, etc.

Marriage is one of the most important transitional periods in human life, which might be the most colorful. Most of the customs, rituals, practices and rituals characteristic of the society occur during the transition periods. This is especially evident during pre-wedding and wedding ceremonies, as on the way to the family hearth, it is necessary to perform a number of actions that are considered favorable for the happiness and well-being of the new family.

In this paper, we would like to pay attention to the marriage customs in Safranbola, considering the works of Turkish authors interested in this topic, as well as the wedding tradition the village Nizhne-Kundriuchenskaya [9, s. 227-240].

Currently, most of the ceremonies of the Safranbolu region are not performed, although some of the customs previously practiced are still found in remote villages of this locality.

Safranbolu is a city and the most developed ilche (the name of the administrativeterritorial unit of the second level in Turkey in Russian is translated as a district, district, county) of the province of Karabuk. It is located at a distance of more than $200 \mathrm{~km}$ north of Ankara. Safranbolu has a rich history dating back to the late Byzantine and Ottoman periods, and its poetic name was given in honor of the growing saffron in this region.

Safranbolu gained prominence in the world due to the magnificent samples of Ottoman architecture, as a result of which the market area of the city was listed as a UNESCO World Heritage Site in 1994 [8].

Like in many parts of Anatolia, weddings in Safranbolu are played in autumn, after finishing all field works. Wedding ceremonies in Safranbolu can be considered in several aspects. First, those wishing to marry must wait for their older brothers and sisters to get married. However, if the elder brother has received consent to marry, the younger brother can marry, if the elder brother gives him his turn. Engaged young people cannot see each other before marriage.

Divorces are not allowed, the second marriage can be concluded only in the event of the death of the spouse. The woman of the deceased marries his brother. It is believed that the honor of the family does not go beyond its limits [9, s. 229]. All these rules are losing their validity today, and are currently not strictly observed, or only in certain areas. 
Thus, when studying the wedding traditions in Safranbolu, it is necessary to take into account their urban and rural features.

In the city, if a young man expressed a desire to marry, then, as a rule, his marriage was arranged after serving in the army. In the village, men got married at an early age, long before the service. Girls were trying to marry up to 20 years. If before that age the girl did not get married, she was called evde kalmış - "stayed at home", küflü "moldy". Note that even the word "evli" is married / married (in the Turkish language there is no grammatical genus). This is a relative adjective, formed from the basic basis ev (house) and is literally translated "with the house", since the - li affix goes back to the postulate ile $[3$, c. 140$]$.

A young man from Safranbolu who wants to marry cannot talk about it with his father, so he lets him know about his desire in an allegorical form, turning his father's shoes. Father, entering the house, and seeing his shoes in this state, understands the situation, but does not give a kind. Girls reveal their desire to get married by bringing extra spoons to the table [6, s. 51].This tradition of allegorical expression of the desire to marry, apparently rooted in antiquity, but it gives the opportunity to go deeper into the culture of Turkish society.

Auspicious days for "kız isteme" or matchmaking for the girl is Monday, Wednesday and Thursday. Other days are not favorable for such an event. Groom's father is called "dünür", and his mother is called "dünürşü" [7]. The groom and his relatives go to the house of the bride, her relatives also gather there. The bride treats the groom to the coffee, if the coffee is sweet, then the groom is to her liking.

When the bride's side decides that it is time to organize «nishan» (engagement), then the groom and his relatives come to the girl's house with gifts. At the engagement ceremony, gifts from the man's house are placed on the fabric. The bride, passing in front of this cloth, gets near the mother-in-law and kisses her hand [6, p. 54]. During the "nishan» (engagement), the bride and groom exchange rings, which then are worn on the ring finger of the right hand. The oldest relative of the young couple traditionally put rings, connected together by a long red ribbon. It is he who also cuts the ribbon after that, as the newlyweds pronounce their wedding vows. It is called Soz Kesimi ("Sez Kesimi", "Gave word," and literally "Cut the words"). Part of the ribbon is cut into small pieces and distributed to all unmarried girls for their quick and happy marriage [4].

After the ceremony, the groom's parents announce the girl as the official bride and give her gold jewelry. The gifting process continues with other relatives of the groom, and in turn, the relatives of the bride give presents to the groom. Friends congratulate the young, accompanying it with hugs, kisses and handshakes.

Nishan in Turkey is not only an engagement, betrothal, an arrangement for a wedding. In Turkish law, the concept of "engagement" ("Nişanlanma") is defined as a "mutual obligation to marry," with legal consequences.

The Civil Code of the Republic of Turkey (art. 82) gives the fact of the engagement ("the communication of two persons of the opposite sex about a mutual desire to marry in the future") a completely official legal status that provides for a mutual commitment of loyalty and respect to each other and leads to the emergence of legal relations between bride and groom.

Under the laws of Turkey, the engagement can be canceled in case of mutual consent of the sides; in so doing, they voluntarily are to return gifts to each other. If in the case of cancellation of the engagement gifts are not returned, this is regarded as "unfounded enrichment" and gifts may be claimed through the court by those who presented them (Article 86 of the Civil Code). If gifts are no longer available, then in accordance with the decision of the court their economic equivalent returns. 
If one of the people, without a justifiable reason, makes a statement on the annulment of the engagement, or the fault of one of them leads to the forced withdrawal of the engagement, the other side has the right to file a claim for compensation for material damage. The court will certainly demand compensation from the guilty party for the costs that the plaintiff made due to the certainty that the marriage would happen: gifts, wedding dresses, ring and engagement costs, a photographer, printing invitations, etc. The "deceived" party may demand compensation for moral harm [4].

Typically, the groom's family bears a large cost of the wedding than the bride's family. Wedding expenses, especially in villages, are discussed by the parties before the wedding.

All expenses can be conditionally divided into:

"Başlık parası" - based on the state of the family - is the amount of money, a garden, a house, or a pair of bulls. bride.

"Süt parası" or "dairy money" - the amount of money or jewelry for the mother of the

Takılar or pendants - gold jewellery.

The date of the wedding is determined when the cost of the wedding becomes obvious. The wedding in the town and village Safranbolu lasted almost a week; it began on Monday and continued until Friday.

On the first day, the bride dowry is transported to the groom's house, and then, to where the newlyweds will live. This is a very picturesque ceremony. In front of the vehicle carrying the dowry, there are musicians playing on drums and a tambourine. The procession moves to the destination, where the young couple will live after the wedding. On this or the next day, the bride's relatives help to arrange the dowry in the house. The next day is the day of the bride's hamam. The bride, her friends and relatives go together in the hamam (the name of the Turkish bath). They wash there and light candles. After that, the girl leaves the hamam; her head is solemnly covered with a beautifully embroidered handkerchief. The same evening, kına gecesi, the night of henna, takes place. This ceremony is for women only. Local musicians entertain guests while henna is being prepared. When henna is ready, the bride puts on a national costume. She sits in the middle of the crowd, and her head is covered with a red shawl with embroidery. Musicians and guests begin to sing sad traditional songs to bring the bride and her parents to tears.

Text of Kına Türküsü

Sallaya sallaya kolum şişti nenni
Kolumdan enteşem düşü nenni
Uyumaz kahpenin pişti nenni
Nenni haşam benim paşam
Yatırayım ak pamuğum nenni
Yük dibine yerin ettim nenni
Üstüne al halı serdim nenni
Sesin ile sabah ettim nenni
Nenni haşam benim paşam nenni
Yatırayım ak pamuğum nenni
Gelin gınan gutlu olsun nenni
Evde dirliğin datlı olsun nenni
Getirin gına yakalım nenni
Yetmezse azca gatalım
Gelinin halın soralım nenni
Nenni haşam benim paşam
Yatırayım ak pamuğum nenni [9, c. 235].


At the same time, the mother of the bride or another elderly woman from the family puts on henna on the girl's hands. Then the dances begin. There is a tradition to buy clothes before betrothal or marriage and keep it in the so-called "wedding bundle". The bridegroom's family usually buys around three to five suits, underwear and shoes for the bride and sends them along with the wedding dress for the night of henna. The bride's family does the same for the groom [5].

Wedding traditions of different nations differ in a large number of details, rites, superstitions, signs, etc., but often have a lot in common. Thus, the "saffron" terrain of Turkey and the forest-steppe Cossack village of Nizhne-Kundruchenskaya are very similar in their wedding rituals.

Thanks to a talented historian, ethnographer, art historian, the first head of the Don museum Khariton Ivanovich Popov, we can learn a lot about the Don region and its history. Many works in statistics, ethnography, notes on the history of culture, materials on the history of the Don Army and Novocherkassk have been written by him. He did a fair amount of research and left to the descendants a wonderful "written memorial", so he called archival documents, understanding their great importance. And this "monument" is stored - H. I. Popov's personal foundation - in the State Archives of the Rostov Region [12]. This is one of the most popular archive funds.

The H.I. Popov fund contains about one and a half thousand cases of great historical value. It is important that it includes copies of documents that have not reached till our time and a collection of materials about Don history, including folklore. We can get acquainted with epics, proverbs, sayings, wedding ceremonies of the villages, Don songs, poems and anecdotes collected by him [2, p. 108-111].

Just like in Turkey, the Cossacks were supposed to marry their children at a young age. Every Cossack in the village of Nizhne-Kundruchenskaya, as soon as his son is eighteen, is going to marry him. He has already noticed a daughter of a settlement; he liked her for quick and handy work. He appeals to a smart woman - a matchmaker, and sends his wife and fiancé to ask the villager for marriage [13]. Thus, we see that priority is given to the girl's abilities, to be a good and hardworking mistress.

Then the parents of the girl, as if not knowing why two women with a young man came to them, ask them what they want. One of the matchmakers says: "We heard that you have a merchandise, and we have a merchant (and at the same time points to the young man). Can we look at your product, maybe our merchant will like it, and he will buy it."

The bride's parents respond that they can. Mother of the bride immediately goes out and says to her daughter that she must clean and go out to the matchmakers. The daughter traditionally obeys her parents, and without saying a word, cleans and goes to the matchmakers, greets and stands near the closet. Time comes for silence. After a few minutes, one of the matchmakers suggests the bride to walk around the room to find out if she limps. The bride fulfills the request of the matchmaker, takes a turn about the room, and then again stands still at the same place. After that, the matchmakers and the groom go out into the yard and ask a young man if he liked the bride, and the bride's parents, left alone with their daughter, ask her if she liked the groom [14].

We can note that these rituals have a very distinctive theatrics, when each participant understands what is happening, but continues to play a role. If the parties like each other, then a day of agreement is appointed. On this day, friends of the bride come and dress her up for the agreement singing a sad song, after which they bring the bride out to the guests.

After that, "the groom's parents say: "Dear in-laws! May our fiancé see his bride?". The bride's parents answer: "So be it, he may!". The groom kisses the bride three times, and the young women sing: 
ISSN 2414-1143

Научный альманах стран Причерноморья. 2018. Том 15. № 3

«Vo sadiku vo zemnom solovej kalinu shchekochet,

Da ni on sadil, da ni on polival, odnako - shchekochet.

Da vo teremu vo vysokom Petenka Varenku celuet,

Da ni on poil, da ni on kormil, a celova'-taki budet» [15].

In general, it should be noted that the Cossacks ritual of matchmaking and the wedding itself was constantly accompanied by various folk songs expressing not only feelings and emotions, but also indirectly giving an idea of the existing traditions in society and the situation in it of one or another category of the population.

«Po rukam svaty vdarili,

Zaryady polozheny,

Zaryady storublevye.

Za Varechku sto rublej,

A za Peten'ku tysyachu» [16].

Parents make a mortgage in case the bride and groom will refuse to marry. They put their hands on the table and appreciate the groom and the bride for a certain amount of money. If it happens that the groom or the bride refuses, then it is normal to charge money that were specified during the agreement from the unwilling party. We can see a vivid similarity between this tradition and Turkish Nishan reflected in their Civil Code [17].

"At the end of the agreement, the groom's parents, with common consent of the bride's parents, appoint a day in which a wedding can be held" [18].

"One day before the wedding, the bride's parents send to the groom cushions, a chest with dresses for their daughter a mirror and other things. All this is carried by brothers and sisters of the bride" [19].

There is an obvious resemblance with the colourful tradition of collecting and transporting the bride in Safranbolu, which in the Cossack version is accompanied by songs corresponding to the occasion.

"When the day of the wedding comes, the groom's parents choose a close 40 years old relative and send him with the groom to the bride's parents, so to take them both to the church to perform the marriage. This chosen person is called the best man. His duty is to protect the groom and his bride from evil eye. That is why, when the bride and groom leave the house to go to church, the best man leads them" [20].

A separate cultural system is incomparable with the other in general, but their essential elements are amenable to formal analysis and classification.

Turkish and Cossack wedding ceremonies consist of a number of elements: matchmaking, bride-show, engagement (or in the Turkish version Söz), a hen party (or its Turkish equivalent - henna night) and, of course, the "musical" part of the rite: prichety and merry wedding songs at Cossacks and sad Turku from the people of Turkey.

Cossacks combined pagan beliefs and Christianity in the wedding traditions of the 19th-century. Such a synthesis is as well typical for a traditional Turkish wedding, where along with Muslim traditions there are remnants of the pre-Islamic period. For thousands of years, the traditions of many peoples of Anatolia, the Mediterranean region, the Middle East, the Caucasus, Eastern Europe, Central Asia and, of course, the ancient world have merged into an unexpected amalgamation, which today is commonly called the Turkish, or Asia Minor culture

Community rituals historically accompanied the most important events in a human life in Ancient Russia. They were sacred being carefully passed through the generations. Many strange traditions were perfectly kept up to now. Rare marriages do without traditional rituals. They make this event solemn, bright and memorable. Rituals at the wedding not only symbolize the unity of lovers, but also connect many generations of their families with the invisible thread. 
Many ancient customs have survived to these days. An urgent task now is the optimization of the interaction of cultures and rituals between peoples of different countries for the development of the individual in rituals and traditions. The use of a single educational and cultural network of people's interaction with each other significantly expands the opportunities for educating young people on popular rituals.

\section{Лumepamypa}

1. Ван Геннеп Арнольд. Обряды перехода. М.: Издательство Восточная литература РАН, 1999.

2. Енина И.А. Исследователь донской старины Харитон Иванович Попов // Донской временник. Ростов-на-Дону: ДГПБ, Сентябрь, 2004.

3. Кононов А.H. Грамматика современного турецкого литературного языка. Москва-Ленинград: Издательство Академии наук СССР, 1956 г.

4. Помолвка в Турции: традиции и законы // Режим URL: http://alanyatoday.ru/articles/99-pomolvka-v-turcii-tradicii-i-zakony.html (Дата обращения: 09.09.2018 г.)

5. Традиции свадьбы и обручения в Турции // Режим URL: https://mjusli.ru/psihologija/lyubovnye-otnosheniya/svadba-v-turcii (Дата обращения: 09.09.2018 г.)

6. AKMAN Eyüp. Safranbolu Folklorundan Örnekler, Ankara: Gazi Kitapevi, 2004. S. 51.

7. K.Ş. 6: Hamdi Acar, 75, Demir 3elik İş3isi, İlkokul Mezunu, Safranbolu.

8. Ö. Ergin, H. Akçın, S. Karakış, H. Şahin (2005). Geleneksel Safranbolu Mimarisinin Kayıt Altına Alınmasına Yönelik CBS Uygulaması: Safranbis, Ankara: TMMOB Harita ve Kadastro Mühendisleri Odası, 10. Türkiye Harita Bilimsel ve Teknik Kurultayı, 28 Mart - 1 Nisan, 2005.

9. Ş. Seher Erol Çalışkan, Şerife Oral. Safranbolu'da evlilik adetleri. Uluslararası Sosyal Araştırmalar Dergisi. The Journal of International Social Research. Cilt: 9 Sayı: 43 Volume: 9 Issue: 43. Nisan 2016, April, 2016. // Режим URL: www.sosyalarastirmalar.com (Дата обращения: 10.09.2018)

10.Safranbis, Ankara: TMMOB Harita ve Kadastro Mühendisleri Odası, 10. Türkiye Harita Bilimsel ve Teknik Kurultayı, 28 Mart-1 Nisan. 2005.

11.Safranbolu.mezuniyet çalişmasi. hazirlayan: Elvan Aydin/yönetici doç.dr. Bülent Yorulmaz. Yakin Dogu Üniversitesi. Fen edebiyat fakültesi. türk dili ve edebiyati. Lefkoşa. 2000.

12. ГАРО. Ф. 55. Попов Харитон Иванович «член Донского областного статистического комитета и комиссии по устройству Донского музея». г. Новочеркасск. 1637-1919 гг.

13.ГАРО. Ф. 55. Оп. 1. Д. 43. Л. 1

14.ГАРО. Ф. 55. Оп. 1. Д. 43. Л. 1 об. - 2

15.ГАРО. Ф. 55. Оп. 1. Д. 43. Л. 4 об. -5

16.ГАРО. Ф. 55. Оп. 1. Д. 43. Л. 5 об.

17.ГАРО. Ф. 55. Оп. 1. Д. 43. Л. 5

18.ГАРО. Ф. 55. Оп. 1. Д. 43. Л. 7

19.ГАРО. Ф. 55. Оп. 1. Д. 43. Л. 9

20.ГАРО. Ф. 55. Оп. 1. Д. 43. Л. 12 об. - 13 


\section{Reference}

1. Van Gennep Arnold. Obryady perekhoda. M.: Izdatelstvo Vostochnaya literatura RAN, 1999. (In Russian)

2. Enina I.A. Issledovatel donskoj stariny Hariton Ivanovich Popov // Donskoj vremennik. Rostov-na-Donu: DGPB, Sentyabr', 2004. (In Russian)

3. Kononov A.N. Grammatika sovremennogo turetskogo literaturnogo yazyka. Moskva-Leningrad: Izdatel'stvo Akademii nauk SSSR, 1956. (In Russian)

4. Pomolvka v Turtsii: traditsii i zakony. Retrieved from: http://alanyatoday.ru/articles/99-pomolvka-v-turcii-tradicii-i-zakony.html (In Russian)

5. Traditsii svad'by i obrucheniya $v$ Turtsii. Retrieved from: https://mjusli.ru/psihologija/lyubovnye-otnosheniya/svadba-v-turcii. (In Russian)

6. AKMAN Eyüp. Safranbolu Folklorundan Örnekler, Ankara: Gazi Kitapevi, 2004. S. 51.

7. K.Ş. 6: Hamdi Acar, 75, Demir Zelik İşzisi, İlkokul Mezunu, Safranbolu.

8. Ö. Ergin, H. Akçın, S. Karakış, H. Şahin (2005). Geleneksel Safranbolu Mimarisinin Kayıt Altına Alınmasına Yönelik CBS Uygulaması: Safranbis, Ankara: TMMOB Harita ve Kadastro Mühendisleri Odası, 10. Türkiye Harita Bilimsel ve Teknik Kurultayı, 28 Mart - 1 Nisan, 2005.

9. Ş. Seher Erol Çalışkan, Şerife Oral. Safranbolu'da evlilik adetleri. Uluslararası Sosyal Araştırmalar Dergisi. The Journal of International Social Research. Cilt: 9 Sayı: 43 Volume: 9 Issue: 43. Nisan 2016, April 2016. Retrieved from: www.sosyalarastirmalar.com 10.

10.Safranbis, Ankara: TMMOB Harita ve Kadastro Mühendisleri Odası, 10. Türkiye Harita Bi-limsel ve Teknik Kurultayı, 28 Mart -1 Nisan. 2005.

11.Safranbolu.mezuniyet çalişmasi. hazirlayan: Elvan Aydin/yönetici doç.dr. Bülent Yorulmaz. Yakin Dogu Üniversitesi. Fen edebiyat fakültesi. türk dili ve edebiyati. Lefkoşa. 2000.

12.GARO. F. 55. Popov Hariton Ivanovich «chlen Donskogo oblastnogo statisticheskogo ko-miteta i komissii po ustrojstvu Donskogo muzeya». g. Novocherkassk. 1637-1919.

13. GARO. F. 55. Op. 1. D. 43. L. 1.

14.GARO. F. 55. Op. 1. D. 43. L. 1 ob. -2.

15.GARO. F. 55. Op. 1. D. 43. L. 4 ob. -5.

16. GARO. F. 55. Op. 1. D. 43. L. 5 ob.

17. GARO. F. 55. Op. 1. D. 43. L. 5.

18. GARO. F. 55. Op. 1. D. 43. L. 7.

19. GARO. F. 55. Op. 1. D. 43. L. 9.

20.GARO. F. 55. Op. 1. D. 43. L. 12 ob. - 13.

July 25, 2018 